\title{
PENERAPAN MODEL PEMBELAJARAN PROBLEM BASED INSTRUCTION UNTUK MENINGKATKAN PRESTASI BELAJAR PPKn
}

\author{
I Ketut Kalih \\ SMA Negeri 1 Mendoyo \\ e-mail: kalih_ikt4@gmail.com
}

\begin{abstract}
Abstrak
Penelitian ini bertujuan mendeskripsikan tentang model pembelajaran Problem Based Instruction (PBI) sebagai upaya untuk meningkatkan prestasi belajar PPKn siswa Kelas X MIPA.2 SMA Negeri 1 Mendoyo Semester 1 Tahun Pelajaran 2018/2019. Subjek penelitian ini adalah siswa kelas X MIPA.2 sebanyak 35 orang yang terdiri dari 17 orang laki-laki dan 18 orang perempuan. Dipilinnya siswa Kelas X MIPA.2 tersebut yaitu karena dari hasil pengamatan awal ditemukan adanya kelemahan prestasi belajar pada siswa tersebut dan peneliti adalah guru mata pelajaran di kelas tersebut yang merasa berkewajiban memperbaiki prestasi belajar siswa melalui perbaikan model pembelajaran. Penelitian tindakan ini dilaksanakan dalam 4(empat) tahap, yaitu: 1). Perencanaan Tindakan, 2). Pelaksanaan Tindakan, 3). Pengamatan/Observasi, dan 4) Refleksi. Data yang diamati selama proses tindakan adalah prestasi belajar siswa yang dicerminkan dari hasil tes dicapai oleh siswa. Setelah data terkumpul dianalisis dengan mencari rerata dan prosentase ketuntasan dengan mengacu pada indikator keberhasilan, dengan metode statistik deskriptif. Hasil yang diperoleh selama proses tindakan, yaitu: 1). Dengan penerapan model Problem Based Instruction dapat meningkatkan prestasi belajar siswa kelas X MIPA.2 SMA Negeri 1 Mendoyo Semester 1 Tahun Pelajaran 2018/2019 dengan rata-rata 75,49 pada Pra Siklus, menjadi 78,03 pada Siklus I, dan meningkat menjadi 82,86 pada Siklus II, dan 2).Dengan penerapan model Pembelajaran Problem Based Instruction dapat meningkatkan prestasi belajar siswa kelas X MIPA.2 SMA Negeri 1 Mendoyo Semester 1 Tahun Pelajaran 2018/2019 dengan ketuntasan 62,86\% pada Pra Siklus, menjadi 82,86\% pada Siklus I, dan meningkat menjadi $94,29 \%$ pada Siklus II. Jadi berdasarkan hasil tersebut dapat disimpulksn bahwa: "Peningkatan prestasi belajar siswa mata pelajaran PPKn dapat dilakukan secara signifikan dengan penerapan model problem based instruction (PBI).
\end{abstract}

Kata kunci: Problem Based Instruction, dan Prestasi Belajar.

\section{Abstract}

This study aimed to describe the Problem Based Instruction (PBI) learning model as an effort to improve the learning achievement of PPKn students in X MIPA.2 SMA Negeri 1 Mendoyo Semester 1 2018/2019 Academic Year. The subjects of this study were 35 students of MIPA.2, consist of 17 men and 18 women. X MIPA.2 students choose because of the results of initial observations that there are weaknesses in student achievement and researchers are subject teachers in the class who feel obliged to improve student achievement through improving learning models. This action research was carried out in 4 (four) stages: 1). Planning, 2). Implementation, 3). Observation, and 4) Reflection. Data observed during the action process are student achievement which reflected from the test results achieved by students. After the data collected, it analyzed by looking for the average and percentage of completeness with reference to the indicators of success, with descriptive statistical methods. The results obtained during the action process: 1). The application of the Problem Based Instruction model can improve student achievement in X MIPA.2 SMA Negeri 1 Mendoyo Semester 1 2018/2019 Academic Year with an average was 75.49 in Pre-Cycle, to 78.03 in Cycle I, and increased to 82, 86 in Cycle II, and 2). The application of the Problem Based Instruction Learning model can improve student achievement in X MIPA.2 SMA Negeri 1 Mendoyo Semester 1 2018/2019 Academic Year with completeness was $62.86 \%$ in Pre-Cycle, to $82,86 \%$ in Cycle I, and increased to $94.29 \%$ in Cycle II. So, based on these results it can be concluded that: "Improving student achievement in PPKn subjects can be done significantly by applying the problem-based instruction (PBI) model.

Keywords: Problem Based Instruction, and Learning Achievement. 


\section{Pendahuluan}

Pendidikan merupakan sesuatu yang memiliki tujuan yang sangat penting untuk diperoleh. Dalam skala nasional, tujuan dalam pendidikan adalah untuk mengembangkan kemampuan dan membentuk watak serta peradaban bangsa yang bermartabat dalam rangka mencerdaskan kehidupan bangsa, serta untuk mengembangkan potensi peserta didik agar menjadi manusia yang beriman dan bertakwa kepada Tuhan Yang Maha Esa, berakhlak mulia, sehat, berilmu, cakap, kreatif, mandiri, dan menjadi warga negara yang demokratis serta bertanggung jawab. Artinya bahwa tujuan pendidikan adalah membentuk orang yang mempunyai sikap atau attitude sosial yang baik, yang mampu bekerja sama dengan lingkungannya, mampu mengutamakan kepentingan umum dari pada kepentingan sendiri atau golongan (Thahir, 2014).

Pengertian pembelajaran menurut ketentuan Undang-Undang RI No. 20 Tahun 2003 tentang Sistem Pendidikan Nasional adalah tenaga kependidikan yang berkualifikasi sebagai guru, dosen, konselor, pamong belajar, widyaiswara. Tutor, instruktur, fasilitator, dan sebutan yang sesuai dengan kekhususannya, serta berpartisipasi dalam menyelenggaran pendidikan.1 Pembelajaran juga didefinisikan sebagai sebuah kegiatan guru mengajar atau membimbing siswa menuju proses pendewasaan diri.2 Pengertian tersebut menekankan pada proses pendewasaan yang artinya mengajar dalam bentuk penyampaian materi tidak serta merta menyampaikan materi (transfer of knowledge), tetapi lebih bagaimana menyampaikan dan mengambil nilai-nilai (transfer of value) dari materi yang diajarkan agar dengan bimbingan pendidik bermanfaat untuk mendewasakan siswa. Selain itu menurut Sugihartono dkk.,3 mendefinisikan pembelajaran lebih operasional, yaitu sebagai suatu upaya yang dilakukan pendidik atau guru secara sengaja dengan tujuan menyampaikan ilmu pengetahuan, dengan cara mengorganisasikan dan menciptakan suatu sistem lingkungan belajar dengan berbagai metode sehingga siswa dapat melakukan kegiatan belajar secara lebih optimal. Konsep pengertian pembelajaran tersebut pada dasarnya menitikberatkan pada proses pembelajaran sebagai sebuah aktivitas yang direncanakan, dilakukan, dan dievaluasi oleh guru. Pembelajaran dilaksanakan secara sengaja untuk mengubah dan membimbing siswa dalam mempelajari sesuatu dari lingkungan dalam bentuk ilmu pengetahuan untuk mengembangkan kemampuan kognitif, afektif, dan psikomotorik menuju kedewasaan siswa. Pembelajaran memiliki tujuan-tujuan tertentu yang akan dicapai dengan memanfaatkan lingkungan sebagai media dan sarana belajar bagi siswa (Kirom, 2017).

Keberhasilan belajar peserta didik dipengaruhi oleh beberapa faktor, dapat berasal dari diri peserta didik sendiri maupun dari guru sebagai pendidik. Faktor yang berasal dari guru di antaranya kemampuan dalam merancang pembelajaran yang mampu menumbuhkan motivasi belajar peserta didik, menciptakan suasana belajar yang menarik dan menyenangkan. Namun pada kenyataannya, peserta didik masih menganggap matematika sebagai mata pelajaran yang menakutkan sehingga susah untuk dipahami. Hal ini terjadi karena pendidik belum mampu mengemas pembelajaran matematika menjadi lebih menyenangkan yang mampu menarik perhatian peserta didik. Sehingga membuat prestasi belajar peserta didik tidak sesuai dengan yang diharapkan (Ayuwanti, 2016).

Berbagai upaya telah dilakukan oleh pemerintah dalam meningkatkan mutu pendidikan di Indonesia, namun sampai saat ini belum memperoleh hasil yang optimal. Fenomena ini dapat dilihat dari hasil belajar, antara lain dari capaian nilai siswa yang masih rendah secara rata-rata. Kurikulum 2013 menuntut perubahan pendekatan pembelajaran yang mulanya berpusat pada guru (teacher centered learning) menjadi pendekatan yang berpusat pada siswa (student-centered learning). Hal ini sesuai dengan tuntutan masa depan anak yang harus memiliki keterampilan berpikir dan belajar (thinking and learning skils), seperti keterampilan memecahkan masalah (problem solving), keterampilan berpikir kritis (critical thinking), kolaborasi, dan keterampilan berkomunikasi yang dapat dimanfaatkan mereka untuk menyongsong masa depan dengan memanfaatkan pengetahuan dan keterampilan yang mereka kuasai untuk memecahkan permasalahan yang dihadapi sehari-hari. Berbagai keterampilan yang diharapkan bisa dimiliki siswa dapat terwujud jika guru mampu 
mengembangkan rencana pembelajaran yang mendorong siswa untuk bekerja sama dan yang menantang siswa untuk berpikir kritis.

Pembelajaran yang menantang biasanya tercetus dari kegiatan pemecahan masalah dalam belajar, seperti yang dipaparkan oleh Sutrisno (2013: 43) yang menyatakan bahwa identifikasi masalah dan pengembangan alternatif pemecahannya mengandung arti bahwa hal-hal yag dipelajari siswa hendaknya memiliki makna yang jelas dan logis dengan proses kehidupannya. Demikian juga apa yang dijelaskan Gestalt bahwa perilaku individu terkait lingkungan sehingga materi yang diajarkan hendaknya memiliki keterkaitan dengan situasi dan kondisi lingkungan kehidupan siswa (life skill).

Proses pembelajaran yang hanya cenderung menghafal konsep bukan memahami konsepakan berakibat kurang aktifnya siswa dalam proses pembelajaran. Pada saat guru menjelaskan materi pembelajaran, siswa akan cenderung pasif dan hanya terpaku pada bahan hafalan saja atau hanya mendengarkan guru menjelaskan materi saja. Akibatnya, siswa belum mampu mengungkapkan suatu pendapat atau bertanya, karena tidak paham dengan materi yang dijelaskan oleh guru. Disamping itu, keterlibatan siswa dalam proses pembelajaran, kurang mampu mengamati, menggolongkan, mengkomunikasikan dan menyimpulkan hasil belajar. Sehingga kemampuan analisis siswa masih rendah. Hal yang sama juga terjadi di SMA Negeri 1 Mendoyo. Berdasarkan hasil observasi yang peneliti lakukan, dapat diketahui bahwa hasil belajar PPKn di Kelas X MIPA.2 SMA Negeri 1 Mendoyo Semester 1 Tahun Pelajaran 2018/2019 yang cenderung dilakukan dengan tujuan menghafal mengakibatkan prestasi belajar siswa hanya mencapai nilai rata-rata 76,23 dengan persentase ketuntasan belajar hanya sebesar $68,18 \%$, hasil tersebut ternyata belum mencapai Kriteria Ketuntasan Minimal (KKM) mata pelajaran yang dipersyaratkan. Dari kegiatan yang dilakukan terdapat beberapa peramasalahan dalam pembelajaran. Permasalahan tersebut di antaranya rendahnya kesiapan siswa untuk mengikuti pelajaran, ini terlihat dari anak kurang aktif mengikuti kegiatan belajar mengajar pada awal proses pembelajaran. Siswa yang kemampuannya kurang, terlihat belum siap belajar yang ditandai siswa tersebut sedikit malas untuk mengerjakan apa yang diperintahkan oleh guru. Siswa tidak mempunyai motivasi dalam mengikuti proses pembelajaran.

Menghadapi kondisi yang sangat mengkhawatirkan, maka perlu adanya upaya perbaikan dalam proses pembelajaran agar dapat meningkatkan keterampilan proses dan hasil dalam pembelajaran PPKn yaitu khususnya pada kemampuan analisis dalam memahami materi. Salah satu alternatif yang digunakan yaitu dengan menggunakan model Problem Based Instruction. Model Problem Based Instruction merupakan model pembelajaran yang berlandaskan paham konstruktivistik yang mengakomodasi keterlibatan siswa dalam belajar dan pemecahan masalah otentik (Arends et al., 2001). Model pembelajaran Problem Based Instruction menggunakan pendekatan pembelajaran siswa pada masalah kehidupan nyata.Problem Based Instruction dikembangkan untuk membantu siswa mengembangkan kemampuan berpikir, pemecahan masalah dan keterampilan intelektual, belajar berbagai peran, melalui pengalaman belajar dalam kehidupan nyata. Arends menjelaskan bahwa Problem Based Instruction merupakan pendekatan belajar yang menggunakan permasalahan autentik dengan maksud untuk menyusun pengetahuan siswa, mengembangkan inkuiri dan keterampilan berpikir tingkat lebih tinggi, mengembangkan kemandirian dan percaya diri(Trianto, 2007: 68).

Dengan penerapan model pembelajaran tersebut diharapkan kemampuan analisis siswa dapat meningkat. Pembelajaran berbasis masalah merupakan suatu cara yang efektif untuk melatih siswa berpikir tingkat tinggi untuk memproses informasi, menyusun dan megembangkan pengetahuan mereka sendiri tentang dunia sosial dan sekitarnya.

\section{Metode}

Untuk mencapai keberhasilan dalam pelaksanaan sebuah penelitian tindakan kelas perlu adanya rancangan. Para ahli telah membuat rancangan tersebut. Sebuah satu rancangan yang penulis ikuti adalah rancangannya menggunakan Model Elliot,1991(dalam Sukidin, Basrowi, Suranto,2002: 52) seperti disampaikan pada gambar berikut: 


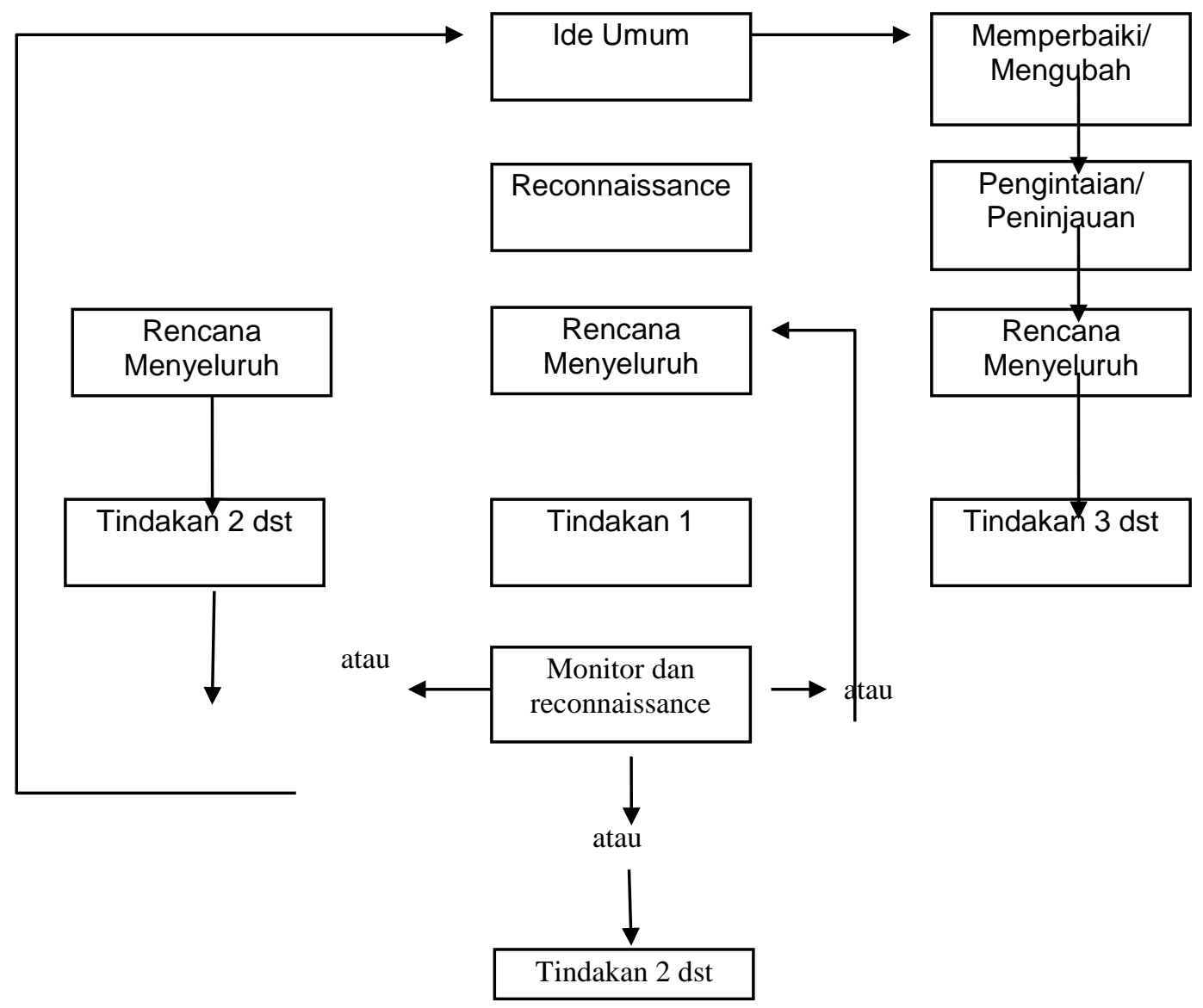

Gambar 1. Rancangan Penelitian

Untuk itu prosedur yang dilakukan di kelas adalah: Mulai dari ide umum. Ide itu dicek dan bila perlu dilakukan perbaikan-perbaikan, ditinjau lagi, dibuat perecanaan menyeluruh, dilakukan tindakan, dimonitor, dicari kebenarannya, dicek yang belum, baik untuk tindakan selanjutnya.

Selanjutnya, sesudah itu dibuat lagi perencanaan untuk tindakan ke-2 berdasar ide umum atau masalah umum, dilakukan perbaikan/perubahan, dicek ulang atau ditinjau lagi ide-ide yang sudah didapat, dibuat perencanaan ulang secara menyeluruh, lalu dilakukan tindakan, kemudian dimonitor dan dievaluasi untuk menentukan tindakan selanjutnya.

Data hasil penelitian dikumpulkan menggunakan instrumen penilaian prestasi belajar. Penilaian dilakukan pada setiap akhir pelaksanaan pembelajaran pada setiap siklus. tujuan dilakukannya penilaian prestasi belajar adalah untuk mendeskripsikan kecakapan belajar siswa dengan model pembelajaran yang diterapkan sehingga dapat diketahui kelebihan dan kekurangan dari model yang dilaksanakan dan dalam penguasaan meteri pelajaran yang telah diajarkan. Dengan pendeskripsian kecakapan tersebut dapat diketahui posisi kemampuan siswa dibandingkan dengan siswa lainnya dan dibandingkan dengan KKM mata pelajaran. Soal-soal yang digunakan dalam penilaian diambilkan dari soal-soal yang terdapat pada Rencana Pelaksanaan Pembelajaran (RPP) pada masing-masing Siklus.

Dengan memperhatikan kondisi awal kemampuan siswa dalam pembelajaran PPKn yang menunjukkan bahwa terdapat siswa yang prestasi belajarnya masih tergolong rendah atau masih berada di bawah KKM, maka indikator keberhasilan yang ditetapkan dalam penelitian ini adalah sesuai dengan KKM PPKn yaitu 75 dan ketuntasan kelasikal 85\%.

Sesuai indikator keberhasilan tersebut, maka hasil penilaian prestasi belajar siswa pada mata pelajaran PPKn memperoleh nilai rata-rata 75 serta ketuntasan klasikal 85, dinyatakan prestasi belajar siswa memenuhi indikator keberhasilan yang ditetapkan dan 
tujuan penelitian dapat dikatakan tercapai atau berhasil. Sebaliknya jika hasil penilaian terhadap prestasi belajar siswa memperoleh nilai rata-rata kurang dari 75 dan ketuntasan klasikal di bawah $85 \%$, maka dinyatakan belum memenuhi indikator keberhasilan tindakan yang ditetapkan dan tindakan perbaikan dilanjutkan ke siklus berikutnya.

\section{Hasil dan Pembahasan}

Hasil obervasi awal menunjukkan, rendahnya prestasi belajar yang dicapai siswa di Kelas X MIPA.2 pada Semester 1. Dari kegiatan awal diperoleh hanya 22 siswa $(62,86 \%)$ yang memperoleh nilai diatas KKM. Dan lagi 13 siswa $(37,14 \%)$ berada di bawah KKM.

Hasil yang diperoleh seluruh kegiatan peningkatan mutu pembelajaran PPKn Kelas $X$ MIPA.2 di SMA Negeri 1 Mendoyo dari 35 orang yang diteliti, terdapat 29 orang $(82,86 \%)$ siswa memperoleh nilai diatas KKM, dan terdapat 6 orang $(17,14 \%)$ siswa memperoleh nilai dibawah KKM. Dengan kehadiran siswa saat tes pada akhir silkus I adalah $100 \%$. Dengan capaian nilai tertinggi adalah 90 dan terendah adalah 70 .

Hasil yang diperoleh dari tes prestasi belajar di Siklus II menunjukkan bahwa kemampuan siswa dalam mengikuti pelajaran sudah cukup baik. Ini terbukti dari rata-rata nilai siswa mencapai 82,86 . Rangkuman hasil penelitian dan peningkatannya dari tiap siklus dapat dilihat pada Tabel 1. berikut.

Tabel 1. Rangkuman hasil penelitian dan peningkatannya

\begin{tabular}{clcccccc}
\hline \multirow{2}{*}{ No. } & \multirow{2}{*}{ Indikator } & \multicolumn{3}{c}{ Hasil Belajar } & \multicolumn{3}{c}{ Peningkatan } \\
& & Pra & I & II & Pra ke I & I ke II & Pra ke II \\
\hline 1 & Means & 75.49 & 78.03 & 82.86 & 2.54 & 4.83 & 7.37 \\
2 & Jml siswa tuntas & 22 & 29 & 33 & 7 & 4 & 11 \\
3 & Prosentase Ketuntasan & 62.86 & 82.86 & 94.29 & 20 & 11.43 & 31.43 \\
\hline
\end{tabular}

Berdasarkan pada Tabel di atas dapat diketahui bahwa:

1) Terjadi peningkatan rata-rata prestasi belajar siswa dari Pra Siklus ke Siklus I sebesar sebesar 2,54 poin,yakni dari 75,49 pada Pra Siklus menjadi 78,03 pada Siklus I; peningkatan dari Siklus I ke Siklus II sebesar 4,83 poin, yakni dari 78,03 pada Siklus I menjadi 82,86 pada Siklus II; dan terjadi peningkatan total dari Pra Siklus ke Siklus II sebesar 7,37 poin, yakni dari 75,49 pada Pra Siklus menjadi 82,86 pada Siklus II.

2) Terjadi peningkatan jumlah siswa yang tuntas belajarnya dari Pra Siklus ke Siklus I sebesar sebesar $20 \%$, yakni dari $62,86 \%$ pada Pra Siklus menjadi $82,86 \%$ pada Siklus I; peningkatan dari Siklus I ke Siklus II sebesar $11,43 \%$ yakni dari $82,86 \%$ pada Siklus I menjadi 94,29\% pada Siklus II; dan peningkatan total dari Pra Siklus ke Siklus II sebesar $31,43 \%$ yakni dari $62,86 \%$ pada Pra Siklus menjadi $94,29 \%$ pada Siklus II.

Untuk mendapatkan gambaran yang lebih jelas tentang perolehan prestasi belajar dan ketuntasan belajar siswa dari Pra Siklus, Siklus I dan Siklus II dapat dilihat pada grafik berikut. 


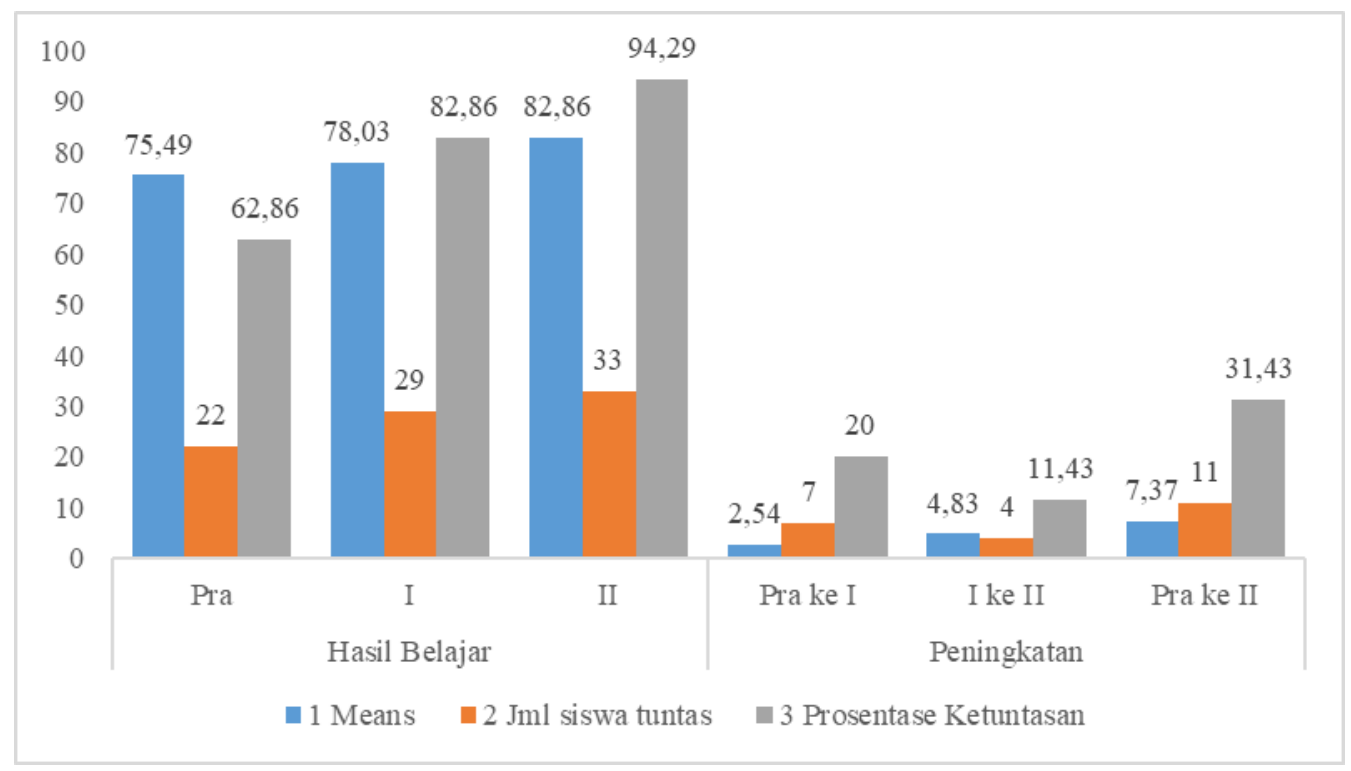

Gambar 2. Grafik rata-rata prestasi belajar siswa dan peningkatannya serta ketuntasan belajar siswa dari pra siklus ke siklus I dan ke siklus II

\section{Simpulan dan Saran}

Berdasarkan hasil refleksi yang menunjukkan rendahnya prestasi belajar siswa pada kondisi awal dan setelah dilakukan perbaikan pembelajaran menggunakan model Problem Based Instruction sebagai solusinya, diperoleh adanya peningkatan yang terjadi terhadap hasil belajar siswa setelah dilakukan tindakan. Dari hasil refleksi yang telah disampaikan dan dengan melihat semua data yang telah dianalisis, maka penulis dapat mengemukakan beberapa simpulan yaitu sebagai berikut.

Dengan penerapan model Problem Based Instruction dapat meningkatkan prestasi belajar siswa kelas X MIPA.2 SMA Negeri 1 Mendoyo Semester 1 Tahun Pelajaran 2018/2019 dengan rata-rata 75,49 pada Pra Siklus, menjadi 78,03 pada Siklus I, dan meningkat menjadi 82,86 pada Siklus II.

Dengan penerapan model Pembelajaran Problem Based Instruction dapat meningkatkan prestasi belajar siswa kelas X MIPA.2 SMA Negeri 1 Mendoyo Semester 1 Tahun Pelajaran 2018/2019 dengan ketuntasan 62,86\% pada Pra Siklus, menjadi 82,86\% pada Siklus I, dan meningkat menjadi $94,29 \%$ pada Siklus II. Paparan di atas membuktikan bahwa pembelajaran model Problem Based Instruction memberi jawaban sesuai terhadap hipotesis penelitian dan jawaban ini sesuai dengan tujuan penelitian yakni "Untuk meningkatkan prestasi belajar PPKn siswa Kelas X MIPA.2 SMA Negeri 1 Mendoyo Semester 1 Tahun Pelajaran 2018/2019 melalui model pembelajaran Problem Based Instruction". Hasil yang dicapai ini terjadi karena penerapan pembelajaran model Problem Based Instruction sangat efektif diterapkan dalam proses pembelajaran yang mengakibatkan siswa aktif, antusias dan dapat memahami materi yang diajarkan sehingga prestasi belajar siswa menjadi meningkat.

Berdasarkan hasil penelitian yang dicapai yakni dapat meningkatkan prestasi belajar PPKn melalui penerapan pembelajaran model Problem Based Instruction, dapat disampaikan saran-saran sebagai berikut.

1. Bagi guru mata pelajaran, pembelajaran model Problem Based Instruction (PBI) dapat dijadikan pilihan dalam melaksanakan pembelajaran karena dari beberapa metode yang ada, metode PBI terbukti dapat meningkatkan prestasi belajar siswa.

2. Bagi peneliti lain, walaupun penelitian ini sudah dapat membuktikan efek utama dari model Problem Based Instruction dalam meningkatkan prestasi belajar, sudah pasti dalam penelitian ini masih ada hal-hal yang belum sempurna dilakukan, oleh karenanya 
disarankan kepada peneliti lain yang berminat meneliti topik yang sama untuk meneliti bagian-bagian yang tidak sempat diteliti.

3. Bagi stakeholders, dapat menggunakan hasil penelitian ini sebagai bahan pertimbangan dalam melakukan pembinaan dan memberikan partisipasi terhadap sekolah.

\section{Daftar Pustaka}

Ayuwanti, Irma. 2016. Meningkatkan Aktivitas Dan Hasil Belajar Matematika Menggunakan Model Pembelajaran Kooperatif Tipe Group Investigation Di Smk Tuma'ninah Yasin Metro . Jurnal SAP Vol. 1 No. 2 Desember 2016

Dimyati dan Mudjiono. 2001. Belajar dan Pembelajaran. Jakarta: Dirjen Dikti.

Djamarah, Syaful Bahri. 2002. Prestasi Belajar dan Kompetensi Guru.Surabaya: Usaha Nasional.

Hamalik, Oemar. 2002. Psikologi Belajar dan Mengajar.Bandung: Sinar Baru.

Joyce, B. And Weil. 2000. Model of Teaching. Needham Heights: Allyn \& Bacon

Kirom, Askhabul . 2017. Peran Guru Dan Peserta Didik Dalam Proses Pembelajaran Berbasis Multikultural . Jurnal Pendidikan Agama Islam Volume 3, Nomor 1, Desember 2017.

Mulyasa, E. 2002.Kurikulum Berbasis Kompetensi Konsep, Karakteristik, Implementasi, dan Inovasi, PT Remaja Rosdakarya, 2002.

Nana Sudjana. 2000. http//www.scribd.com/doc/9037208/.

Oemar Hamalik. 2003. Proses Belajar Mengajar. Bumi Aksara: Jakarta.

Sardiman, A.M. 1988. Interaksi dan Motivasi Belajar-Mengajar Pedoman bagi Guru dan Calon Guru.Jakarta: Rajawali Pers.

Slamet. 2000. Belajar dan Faktor-Faktor yang Mempengaruhinya. Jakarta: Rineka Cipta.

Thahir, Andi. 2014. Pengaruh Bimbingan Belajar Terhadap Prestasi Belajar Siswa Pondok Pesantren Madrasah Aliyah Al-Utrujiyyah Kota Karang . Jurnal Bimbingan dan Konseling 01 (2) (2014)

Trianto, 2007.Model-model Pembelajaran Inovatif Berorientasi Konstruktivistik. Jakarta: Prestasi Pustaka 